\title{
Expression of neuromedin B in adipose tissue and its regulation by changes in energy balance
}

\author{
N Hoggard, S Bashir, M Cruickshank, J D B Miller² and J R Speakman ${ }^{1}$ \\ Rowett Research Institute, Aberdeen Centre for Energy Regulation and Obesity (ACERO), Bucksburn, Aberdeen AB21 9SB, UK \\ ${ }^{1}$ ACERO, School of Biological Sciences, University of Aberdeen, Aberdeen, UK \\ ${ }^{2}$ Department of Surgery, Dr Gray's Hospital, Elgin, UK \\ (Correspondence should be addressed to N Hoggard; Email: nh@ rowett.ac.uk)
}

\begin{abstract}
Bombesin is one of the most powerful substances showing anorexic effects in the hypothalamus (Moody TW \& Merali Z 2004 Bombesin-like peptides and associated receptors within the brain: distribution and behavioral implications. Peptides 25 511-520). In mammals, neuromedin B (NMB) is one member of a family of bombesin-like peptides, which have been shown to reduce food intake when administered systemically. Using Taqman real-time PCR with specific primers, we report the expression of NMB mRNA in both human and rodent adipose tissue. Expression of NMB in rodent epididymal adipose tissue was higher than in other tissues studied. Expression of NMB in adipose tissue appears to be regulated by changes in energy balance and leptin. It is decreased fourfold in the epididymal fat depot of ob/ob mice when compared with the same fat depot in lean mice. It is further decreased with the intra-peritoneally (i.p.) administration of leptin in both lean and obese $o b / o b$ mice. This may relate to its function in food intake regulation or to changes in energy expenditure. We demonstrate that NMB expression in rodent adipose tissue is decreased in cold exposed animals. However, when we investigated the effects of NMB on resting metabolic rate by i.p. injection, there was no effect on oxygen consumption, $\mathrm{RQ}$ or physical activity when compared with saline-treated controls. In conclusion, NMB is expressed in both human and rodent adipose tissue and appears to be regulated by changes in energy balance. Given its anorexic effects centrally, it may form part of a new adipose tissue - hypothalamic axis regulating food intake.
\end{abstract}

Journal of Molecular Endocrinology (2007) 39, 199-210

\section{Introduction}

Bombesin $(\mathrm{BN})$, originally extracted from frog skin, is also active in mammals (Anastasi et al. 1971). It has various physiological effects, for example on food intake, insulin secretion, gastric secretion and contractive effects on the colon or ileum (Erspamer et al. 1970). Neuromedin B (NMB) is a member of a family of BN-like peptides, which in mammals also include gastrin-releasing peptide (GRP) and neuromedin (McDonald et al. 1979, Minamino et al. 1988). These peptides are widely expressed in the pituitary, brain, pancreas, adrenal and gastrointestinal tract, but have not previously been reported in adipose tissue (Ohki-Hamazaki et al. 2005). Their receptors are also widely distributed not only in the key areas in the central nervous system (CNS) involved in energy balance regulation (Moody \& Merali 2004) but also in the periphery (Merali et al. 1999). The BN-like peptides have been shown to bind a range of $\mathrm{BN}$ receptors with varying affinity. The $\mathrm{BN}$ receptors have been sub-classified into four subtypes, NMB (NMB-preferring receptor), GRP (GRP-preferring receptor), bombesin receptor subtype-3 (BRS-3) (which shows low affinity with both NMB and GRP) and BRS-4 receptors, although the fourth subtype has been found only in amphibian tissues (Nagalla et al. 1995). The amino acid sequences of all the $\mathrm{BN}$ receptors are well conserved across species (Ohki-Hamazaki et al. 2005).

Given the cross reactivity of NMB for all the BN receptors, it is often difficult to determine which functions are specific to NMB as opposed to the other BN-like peptides (e.g. GRP). An indication of this is provided by knockout studies of the receptors. GRP receptor knockout mice and mice lacking the BRS-3 receptor are obese (Ohki-Hamazaki et al. 1997, Ladenheim et al. 2002). However, mice lacking the NMB receptor are not obese, but there is an effect on the serotonergic (5-hydroxytryptamine(HT)) system which is linked to food intake (Yamano et al. 2002).

In humans, the receptor to NMB has been identified in visceral adipocytes (Yang et al. 2003) and Bouchard et al. (2004) have shown that NMB is a potential candidate gene for eating disorders (Bouchard et al. 2004). They also identified a missense mutation in the $N M B$ gene, which resulted in twice as much body fat gain over a 6-year follow-up period when compared with the wild type population (Bouchard et al. 2004). Given that the receptor to NMB is present in human adipose

DOI: 10.1677/JME-07-0071 Online version via http://www.endocrinology-journals.org 
tissue, we hypothesised that NMB may be secreted by adipose tissue and act in a paracrine or endocrine manner to regulate energy balance.

Here we show that NMB is expressed in mature adipocytes and adipocytes differentiated in primary culture as well as the stromal vascular fraction of adipose tissue. We show that its expression in adipose tissue is regulated by changes in energy balance including obesity and cold exposure, but that peripheral injection of NMB does not affect energy expenditure. We further show that $\mathrm{NMB}$ is regulated by leptin in vivo and by leptin, triiodothyronine $\left(\mathrm{T}_{3}\right)$, thyroxine $\left(\mathrm{T}_{4}\right)$, interleukin 6 (IL6) and lipopolysaccharide (LPS) in vitro in differentiated mature 3T3-L1 adipocytes.

\section{Materials and methods}

\section{Animals}

Wild type, obese $o b / o b$ and obese $d b / d b$ male mice on the C57BL/ 6 background (all $\sim 11$ weeks of age) were purchased from Harlan UK (Bicester, Oxon, UK). Animals were maintained on a 12:12 $\mathrm{h}$ photoperiod with lights on at $0800 \mathrm{~h}$. Room temperature was controlled at $20^{\circ} \mathrm{C}\left( \pm 1{ }^{\circ} \mathrm{C}\right)$ and humidity was regulated to be $<70 \%$. Food (Biosure CRM pelleted chow; Special Diets Services, Witham Essex, UK) and water were available ad libitum unless stated. The CRM pelleted chow has an estimated metabolisable energy of $12-13 \mathrm{MJ} / \mathrm{kg}$, partitioned as Atwater fuel energy, protein $22 \%$, fat $9 \%$ and carbohydrate $69 \%$.

All procedures were licensed under the UK Animals (Scientific Procedures) Act of 1986 and received ethical approval from the University of Aberdeen or Rowett Research Institute Ethical Review Committee.

\section{Intra-peritoneally (i.p.) leptin administration}

To determine the effect of the i.p. administration of leptin on the expression of NMB in adipose tissue, 24 obese $(o b / o b)$ mice and 24 lean $(+/$ ? $)$ mice were used. Half the mice in each group, with ad libitum access to food and water, were injected i.p. once only with leptin $(2 \mathrm{mg} / \mathrm{kg}$ body weight in saline) in the middle of the light phase. The other half received saline $(100 \mu \mathrm{l})$ only. After 1 or $4 \mathrm{~h}$, the mice were killed by cervical dislocation and tissues collected for analysis. Each experimental group consisted of six mice. All murine tissues described were carefully dissected and then frozen immediately in liquid nitrogen and stored at $-80^{\circ} \mathrm{C}$ until extraction of RNA.

\section{Cold exposure}

To examine the effects of cold exposure, C57BL/6 mice were singly housed into M3 shoebox cages with sawdust but no bedding, at $4{ }^{\circ} \mathrm{C}$ over three orders of magnitude in duration, for 6 (control), 60, 600 and $6000 \mathrm{~min}(n=5$ per time point). The start time of exposure to cold were staggered so that the time at which exposure ended was always noon. The mice were singly housed to prevent social thermoregulation and had been singly housed in the warm prior to exposure to the cold. Animals were maintained on a 12:12 $\mathrm{h}$ photoperiod with lights on at $0800 \mathrm{~h}$. The adipose tissue (epididymal and subcutaneous) was carefully dissected and then frozen immediately in liquid nitrogen and stored at $-80^{\circ} \mathrm{C}$ until extraction of RNA.

\section{Energy expenditure}

Measurements of resting metabolism were made using an open-flow indirect calorimetry apparatus as previously described (Arch et al. 2006). Because our systems include an $\mathrm{O}_{2}$ and a $\mathrm{CO}_{2}$ analyser uniquely dedicated to each metabolic chamber, these systems permit continuous logging of $\mathrm{O}_{2}$ consumption and $\mathrm{CO}_{2}$ production at a user defined interval - in this case every $15 \mathrm{~s}$. The detailed time course of response allowed us to identify periods when the animals had elevated metabolism due to physical activity and thereby quantify not only resting metabolism but also the expenditure of energy on spontaneous physical activity (Hoggard et al. 2004).

We measured metabolic rate in lean wild type C57BL/ 6 mice $(n=16,8$ per group) prior to $(1.5 \mathrm{~h})$ and following $(4 \mathrm{~h})$ i.p. administration of either saline or NMB (32 nmol $/ \mathrm{kg}$ body weight) solubilised in saline (Sigma N3762). Mice were not fed while in the respirometry chamber. Metabolism measurements started between $0900 \mathrm{~h}$ and $1000 \mathrm{~h}$. Prior to measurements, all the mice were weighed and their body temperatures were measured using a rectal probe (Model 2751-K and K type thermocouple, Digitron Instrumentation Ltd, Devon, UK). The rectal probe was inserted $2 \cdot 5-3 \mathrm{~cm}$ into the rectum for $\sim 5 \mathrm{~s}$.

Mice were placed in the respirometry chamber at $20{ }^{\circ} \mathrm{C}$ (the temperature at which the mice were routinely housed) for $90 \mathrm{~min}$ to obtain a pre-injection baseline measurement. They were then removed from the chamber and injected i.p. with either NMB in saline $(n=8)$ or saline $(200 \mu \mathrm{l}, n=8)$ alone and within $30 \mathrm{~s}$ replaced in the respirometry chamber. Solutions were injected into the mice blind of the solution give to the animal. Metabolism was then monitored for a further $4 \mathrm{~h}$. After $4 \mathrm{~h}$, animals were removed from the chamber and their body weights and body temperatures remeasured. Animals were then killed as described above.

Positive excursions of $\mathrm{CO}_{2}$ and reductions in $\mathrm{O}_{2}$ concentration in the traces connected with physical activity were very obvious. To eliminate the effects of activity on metabolism in both the pre- and postinjection phases we measured $\mathrm{VO}_{2}$ and $\mathrm{VCO}_{2}$ as the 
lowest consecutive $150 \mathrm{~s}$ of metabolism. Each animal therefore acted as its own weight-matched control. We defined the treatment effect as the difference between the pre- and post-injection measures of RMR. We used two inclusion zones for the post-injection measures of resting metabolic rate (RMR): first, the entire period between placing animals back into the chamber and their removal $4 \mathrm{~h}$ later and second, a restricted period of $6000 \mathrm{~s}$ commencing $4500 \mathrm{~s}$ after the animals were replaced in the chambers. Respiratory exchange ratio (RQ) was calculated as the minimum $\mathrm{CO}_{2}$ production divided by the minimum $\mathrm{O}_{2}$ consumption in pre- and post-injection phases. We estimated the levels of energy expended on physical activity by taking the average metabolic rate throughout the entire pre- and postinjection periods and subtracted from this the resting metabolic rate. In the post-injection period, we performed this analysis both including and excluding the period of elevated activity that mice exhibited for around 15-20 min after being returned to the metabolic chamber. All analyses of metabolism were performed blind of the treatment.

\section{Mature adipocyte isolation}

Mature adipocytes were isolated from the murine epididymal fat depot of 11-week-old C57BL/6 male mice. In brief, following dissection the white adipose tissue (WAT) samples were placed in 1\% Albumin buffer (1\% BSA in HEPES buffer). Following removal of blood vessels, the tissue was diced and transferred to collagenase buffer $(1 \mathrm{mg} / \mathrm{ml}$ collagenase type II in HEPES buffer, $\mathrm{pH} 7 \cdot 4$ ) and placed in a shaking incubator at $37^{\circ} \mathrm{C}$ for $60 \mathrm{~min}$, or until digestion was complete. The digested tissue was passed through a $250 \mu \mathrm{m}$ mesh and centrifuged at $200 \mathrm{~g}$ for $10 \mathrm{~min}$ to pellet the stromal vascular fraction. The mature fat cells floating at the top were then transferred to fresh tubes and treated to three washes with HEPES buffer with centrifugation at $200 \mathrm{~g}$ for $5 \mathrm{~min}$. Finally, excess buffer was removed and Tri-pure isolation reagent (Roche Diagnostics Ltd) added. The stromal vascular pellet was incubated for $10 \mathrm{~min}$ in erythrocyte lysis buffer $\left(154 \mathrm{mM} \mathrm{NH}_{4} \mathrm{Cl}, 5 \cdot 7 \mathrm{mM} \mathrm{K}_{2} \mathrm{HPO}_{4}\right.$ and $0 \cdot 1 \mathrm{mM}$ EDTA, $\mathrm{pH} 7 \cdot 3$ ). The suspension was then centrifuged at $200 \mathrm{~g}$ for $10 \mathrm{~min}$ and the pellet was resuspended in Tri-pure isolation reagent (Roche Diagnostics Ltd).

\section{T3-L1 Cell culture}

3T3-L1 cells were obtained from the LGC Promochem (Teddington, Middlesex, UK) and cultured at $37^{\circ} \mathrm{C}$ in a humidified atmosphere of $5 \% \mathrm{CO}_{2}-95 \%$ air. The cells were maintained in culture medium containing the following: Dulbecco's modified Eagle's medium (DMEM; Invitrogen) with $25 \mathrm{mM}$ glucose, $1 \mathrm{mM}$ pyruvate, $4.02 \mathrm{mM}$ L-alanyl-L-glutamine and $10 \%$ foetal calf serum (FCS; Sigma). Differentiation was initiated $24 \mathrm{~h}$ after confluence by incubation for 2 days in culture medium containing $0.25 \mu \mathrm{M}$ dexamethasone (Dex), $0.5 \mathrm{mM}$ 3-isobutyl-1-methyl-xanthine and $5 \mu \mathrm{g} / \mathrm{ml}$ insulin (Sigma). This was followed by maintenance in feeding medium (renewed every 2 out of 3 days) consisting of culture medium containing $5 \mu \mathrm{g} / \mathrm{ml}$ insulin. Cells were fully differentiated by day 11 with over $90 \%$ of the cells containing lipid droplets. The cells were maintained for up to 11 days after the induction of differentiation and sampled every 2-3 days. In some experiments as described fully differentiated adipocytes at day 11 were incubated for a further $24 \mathrm{~h}$ with leptin $(1000,100$ and $10 \mathrm{nM}$ ), (IL6; $100 \mathrm{ng} / \mathrm{ml})$, (LPS; $75 \mathrm{ng} / \mathrm{ml}),\left(\mathrm{T}_{3} ; 1000\right.$ and $\left.100 \mathrm{nM}\right)$, $\left(\mathrm{T}_{4} ; 1000\right.$ and $\left.100 \mathrm{nM}\right)$ or $(\mathrm{Dex} ; 20 \mathrm{nM})$. All reagents were purchased from Sigma. Cells were harvested and RNA extracted as described below for PCR analysis.

\section{Human adipose tissue - subjects and protocols}

Human subcutaneous adipose tissue was taken from the abdominal subcutaneous wall, during an operation for vertical banded gastroplasty, from two obese female patients. The patients were aged $40 \pm 2$ years with a BMI of $38 \cdot 6 \pm 1 \cdot 3$. Adipose tissue samples were obtained within $5 \mathrm{~min}$ of the tissue being extracted from the patients and frozen immediately in liquid nitrogen. Subjects had fasted overnight prior to surgery. All patients provided informed written consent before inclusion in the study. The study was approved by the Grampian Research Ethics committee.

\section{Real-time quantitative PCR (RTQ-PCR; Taqman system)}

RNA was extracted using the Tri-pure isolation reagent (Roche Diagnostics Ltd) for DNA-free RNA, following manufacturer's instructions (AMS Biotechnologies, Abingdon, Oxon, UK). RNA was accurately quantified on the Agilent 2100 Bioanalyzer (Agilent Technologies, South Queensferry, West Lothian, UK). This also shows the quality of the RNA extracted from the tissues. Only RNA showing no degradation was processed further. Reverse transcription was carried out on $3-5 \mu \mathrm{g}$ RNA using the SuperScript first strand synthesis system (Invitrogen Cat No: 12371-019) according to manufacturer's instructions. The cDNA was amplified by PCR using either rodent specific (Applied Biosystems, Foster City, CA, USA cat number Mm00471534_m1) or human specific (Applied Biosystems cat number Hs00175085_m1) primers for the NMB gene or rodent 
specific primers for the leptin gene (Applied Biosystems cat number Mm00434759_m1).

The method for the measurement of gene expression is based upon the $5^{\prime}$ exonuclease activity of the Taq polymerase. Briefly, within the amplicon defined by a gene-specific oligonucleotide primer pair an oligonucleotide probe labelled with two fluorescent dyes is designed. As long as the probe is intact, the emission of a reporter dye (i.e. 6-carboxy-fluorescein, FAM) at the $5^{\prime}$-end is quenched by the second fluorescence dye (6-carboxy-tetramethyl-rhodamine, TAMRA) at the $3^{\prime}$-end. During the extension phase of the PCR, the Taq polymerase cleaves the probe releasing the reporter dye. An automated photometric detector combined with special software (ABI Prism 7700 Sequence Detection System, Perkin-Elmer Applied Biosystems) monitors the increasing reporter dye emission. The algorithm normalises the signal to an internal reference (DRn) and calculates the threshold cycle number (CT), when the $\mathrm{DRn}$ reaches ten times the s.D. of the baseline. The CT values of the probes are interpolated to an external reference curve constructed by plotting the relative or absolute amounts of a serial dilution of a known template versus the corresponding CT values. Commercial reagents (TaqMan PCR Reagent Kit, Perkin-Elmer) and conditions were employed according to manufacturer's protocol. cDNA ( $2.5 \mathrm{ml}$; reverse transcription mixture) and oligonucleotides with a final concentration of $300 \mathrm{nmol} / 1$ of primers and $200 \mathrm{nmol} / 1$ of TaqMan hybridisation probe were added to $25 \mathrm{ml}$ reaction mix.

PCR was performed on an Applied Biosystems ABI Prism 7700 sequence detection system (Perkin-Elmer Applied Biosystems Inc.) under the following conditions: $50{ }^{\circ} \mathrm{C}(2 \mathrm{~min})$ for $1 \mathrm{cycle}, 95{ }^{\circ} \mathrm{C}(10 \mathrm{~min})$ for 1 cycle, $95{ }^{\circ} \mathrm{C}(15 \mathrm{~s}), 60^{\circ} \mathrm{C}(1 \mathrm{~min})$ for 40 cycles. All samples were run in triplicate and were all within the standard curve.

A serial dilution of known copy numbers of a PCR product served as reference (standard curve) providing a relative quantification of the unknown samples. Target gene expression was related to the housekeeping genes' $\beta$-actin (primers obtained from Applied Biosystems cat number rodent Mm00607939_s1 and human $4352935 \mathrm{E}$ ) and GAPDH (primers obtained from Applied Biosystems cat number Mm99999915_g1), following manufacturer's instructions. All of the primers and probes were purchased from Applied Biosystems as TaqMan Gene Expression Assays which have been designed and validated by Applied Biosystems. Further details of all the primers are available at the Applied Biosystems website under the catalogue numbers provided.

Values were standardised to $\beta$-actin and expressed as a percentage of the control. Similar data were obtained when the values were standardised to glyceraldehyde-3phosphate dehydrogenase (GAPDH) (data not shown). Controls were carried out to eliminate any potential for spurious amplification from contaminating genomic DNA.

\section{Statistical analysis}

Between-group comparisons were made using unpaired Student's $t$-tests. Results were considered statistically significant if the $P$ value was $\leq 0 \cdot 05$. Where appropriate the data were also analysed by two-way ANOVA using Minitab version 14.

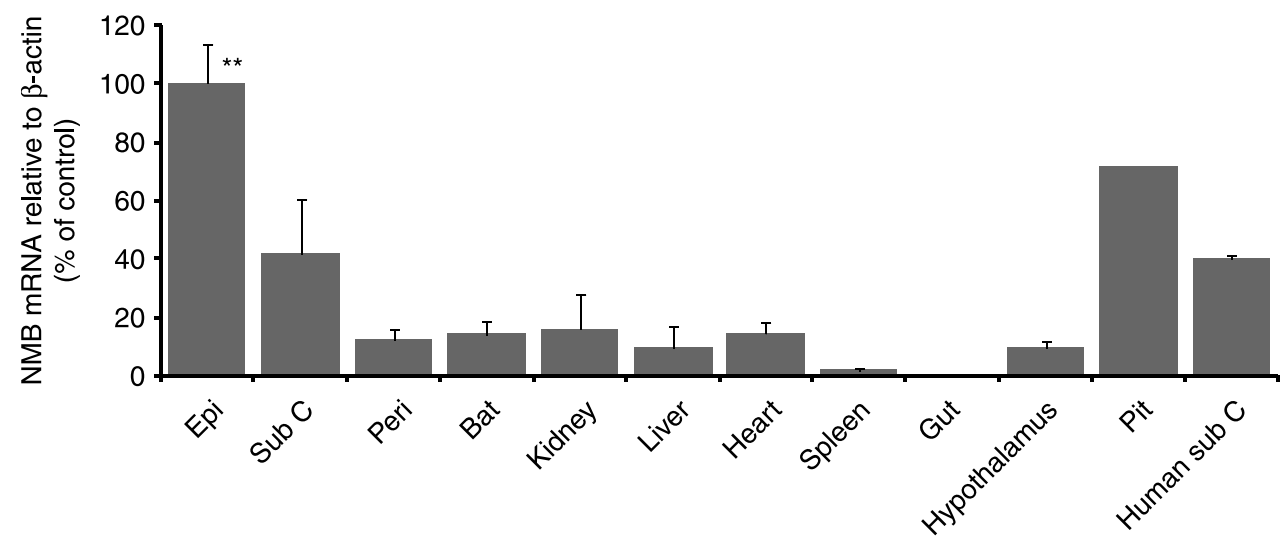

Figure 1 Expression of NMB (neuromedin B) mRNA is higher in murine epididymal adipose tissue (Epi) when compared with subcutaneous adipose tissue (sub C), perirenal adipose tissue (Peri), brown adipose tissue (Bat), kidney, liver, heart, spleen, gut, hypothalamus and pituitary (Pit) dissected from lean C57BL/6 mice and human subcutaneous (Human Sub $C$ ) adipose tissue ( ${ }^{* \star} P \leq 0 \cdot 01$ ). NMB mRNA was determined by qRT-PCR using the Taqman assay and primers specific for murine NMB and human NMB respectively. Results are expressed as a percentage of the control that in this case is taken as expression in the lean rodent epididymal fat depot (the highest expression), $n=3$ for each point ( $n=2$ for human tissue) \pm s.E.M. related to the expression of the housekeeping gene $\beta$-actin. This was replicated in independent amplifications. 


\section{Results}

\section{Expression of NMB mRNA in murine tissues and in human subcutaneous adipose tissue}

To determine the level of expression of NMB mRNA in murine tissues, we carried out real-time PCR with the Taqman system on a range of tissues dissected from lean C57BL/6 mice, which had ad libitum access to food and water and compared the level of expression with that for human subcutaneous adipose tissue obtained from the abdominal wall of two obese subjects (Fig. 1).

NMB is highly expressed in murine epididymal adipose tissue when compared with a range of other tissues including other adipose tissue depots studied $(P \leq 0 \cdot 05)$. NMB expression was greater by eightfold when compared with other tissues studied including kidney, liver spleen, gut, hypothalamus and heart. Due to the high level of NMB mRNA expression in the murine epididymal adipose tissue, data are presented for this fat depot in subsequent experiments, but the same trend was also observed in the subcutaneous fat depot. NMB mRNA was also detected in brown adipose tissue in keeping with a possible role for NMB in thermoregulation. NMB was expressed at high levels in the pituitary of these mice in keeping with previous reports (Houben et al. 1993). NMB was also detected in human adipose tissue (Fig. 1).

We tried to confirm that the differences in gene expression paralleled differences in protein by western blotting but a commercial porcine antiserum (Acris Antibodies, Hiddenhausen, Germany) did not cross react sufficiently to murine NMB (data not shown).

\section{Expression of NMB mRNA in the adipose tissue of obese $o b / o b$ and $d b / d b$ mice compared with C57BL/6 lean mice. Effect of i.p. administration of leptin when compared with saline-treated controls}

To determine whether NMB mRNA in adipose tissue is regulated by changes in energy balance we carried out real-time PCR using the Taqman assay with primers specific to NMB (Fig. 2). NMB is decreased fourfold in the epididymal fat depot of the $o b / o b$ mouse when compared with the same fat depot in lean mice on the same C57BL/6 background $(P \leq 0 \cdot 05)$. It is further decreased with the i.p. administration of leptin $(2 \mathrm{mg}$ / $\mathrm{kg}$ of body weight) in both lean and obese $o b / o b$ mice after $4 \mathrm{~h}(P \leq 0 \cdot 05)$. Using two-way ANOVA, there is a significant effect of both leptin $(P=0.02)$ and obesity $(P=0 \cdot 02)$ as well as an interaction of the two $(P=0 \cdot 04)$ on NMB gene expression. A similar trend was also observed after $1 \mathrm{~h}$ i.p. administration of leptin (data not shown).

NMB was also elevated in lean controls when compared with obese $d b / d b$ mice, which have a defect in leptin signalling $(P \leq 0 \cdot 005)$ in agreement with the observed difference between the lean and obese $o b / o b$ mice (Fig. 2).

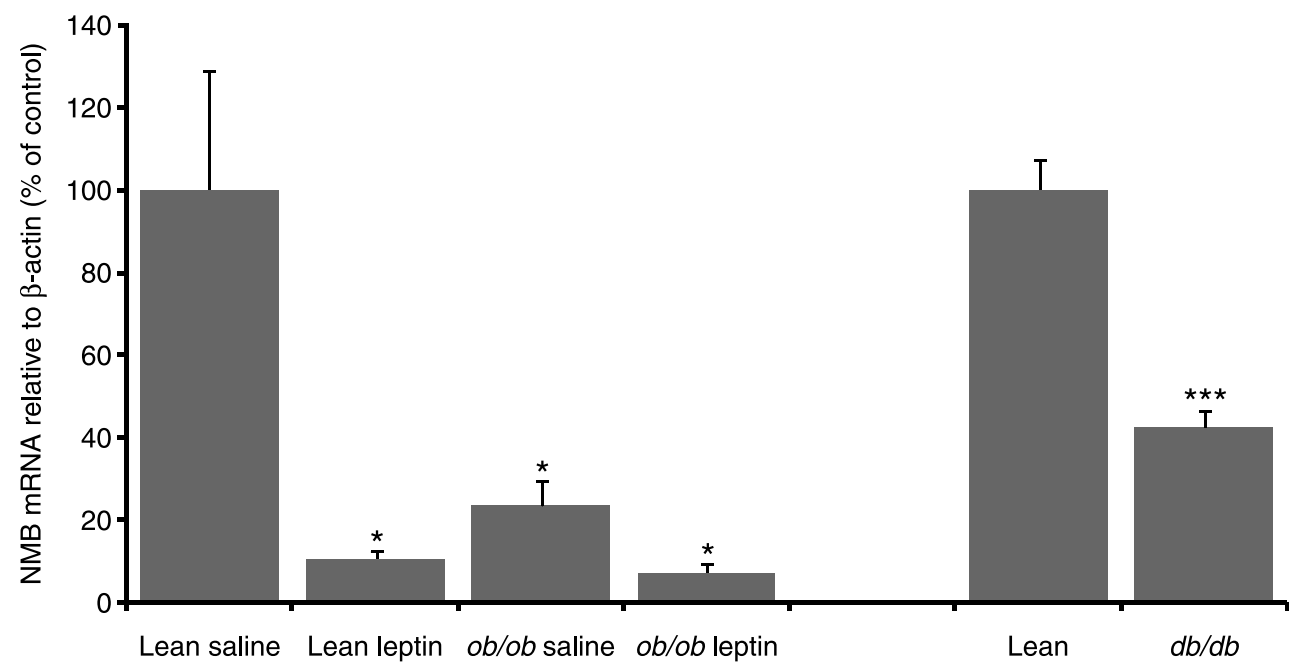

Figure 2 NMB mRNA is higher in the epididymal adipose tissue depot of lean C57BL6 mice $(P \leq 0.05)$ when compared with $o b / o b$ and $d b / d b$ mice on the same background. The administration of leptin i.p. at $2 \mathrm{mg} / \mathrm{kg}$ of body weight to lean and $o b / o b$ mice decreases NMB mRNA in the adipose tissue when compared with saline-treated controls after $4 \mathrm{~h}(P \leq 0.05)$. NMB mRNA was determined by qRT-PCR using the Taqman assay and primers specific for murine NMB. Results are expressed as a percentage of the control that in this case is taken as the expression in the fat depot of the lean saline-treated mice (the highest expression), $n=6$ for each point \pm S.E.M. related to the expression of the housekeeping gene $\beta$-actin. This was replicated in independent amplifications. 


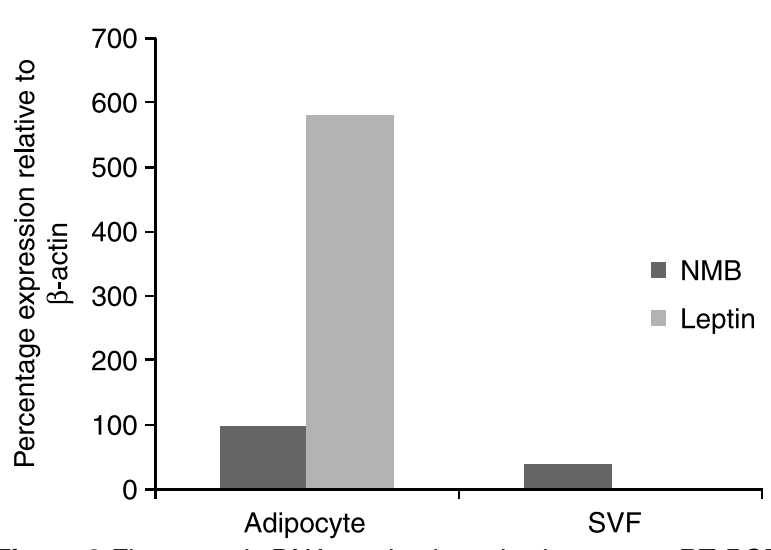

Figure 3 First strand cDNA synthesis and subsequent qRT-PCR analysis were performed on RNA isolated from stromal vascular and mature adipocyte fractions separated by collagenase digestion from epididymal fat dissected from C57BL/6 mice. NMB and leptin mRNA was determined by qRT-PCR using the Taqman assay and primers specific for murine NMB and leptin respectively. Results are expressed relative to the expression of the housekeeping gene $\beta$-actin and as a percentage of the NMB expression in the mature adipocyte fraction. SVF, stromal vascular fraction; Adipocyte, mature adipocytes.

\section{NMB mRNA is expressed in mature adipocytes and the stromal vascular fraction}

Adipose tissue is heterogeneous at the cellular level, mature adipocytes comprising no more than $50 \%$ of the total cell content. To establish the cellular localisation of NMB in WAT, epididymal fat from C57BL/6 mice was fractionated by collagenase digestion into stromal vascular and mature adipocyte components. NMB mRNA was measured using the Taqman assay and products for NMB mRNA were observed in the

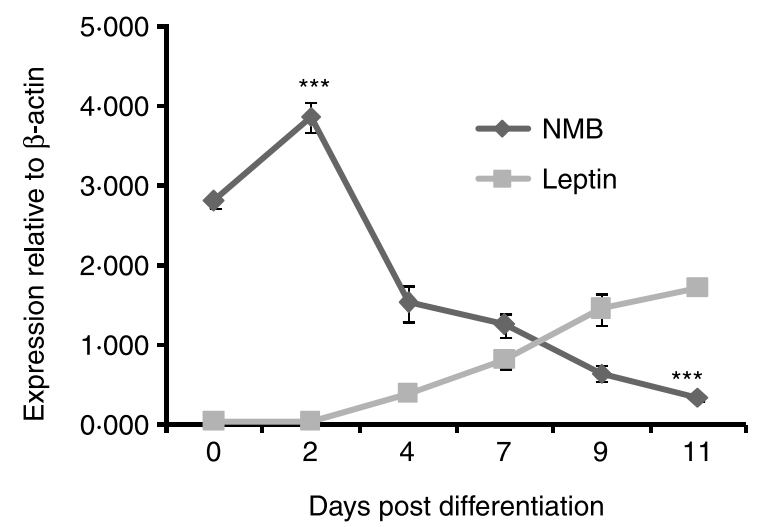

Figure 4 NMB and leptin gene expression in 3T3-L1 cells before and after differentiation into mature adipocytes. Differentiation was initiated on day 0 . NMB and leptin mRNA was determined by qRT-PCR using the Taqman assay and primers specific for murine NMB and leptin respectively. Results are expressed relative to the expression of the housekeeping gene, $\beta$-actin. $n=3$ for each point \pm S.E.M. This was replicated in independent amplifications. ${ }^{\star \star \star} P \leq 0 \cdot 001$. adipocyte and stromal vascular fractions (Fig. 3). As expected, leptin mRNA expression was expressed exclusively in the mature adipocytes.

\section{NMB mRNA is expressed in the murine adipocyte 3T3- L1 cell line}

To determine the pattern of expression of NMB mRNA as preadipocytes are differentiated into mature adipocytes, NMB mRNA was measured using the Taqman assay in the 3T3-L1 adipocyte cell line (Fig. 4).

NMB mRNA can be readily detected in preadipocytes and differentiated mature adipocytes. NMB mRNA increased $(P \leq 0 \cdot 001)$ during the first 2 days of culture in medium containing 0.25 $\mu \mathrm{M}$ Dex, $0.5 \mathrm{mM}$ 3-isobutyl1-methyl-xanthine and $5 \mu \mathrm{g} / \mathrm{ml}$ insulin. Thereafter, NMB mRNA levels decreased with increasing differentiation of the preadipocytes into mature adipocytes $(P \leq 0 \cdot 001)$. As expected, leptin mRNA levels increased with increasing differentiation of the preadipocytes into mature adipocytes as previously reported (Rentsch \& Chiesi 1996). In addition, differentiation of the 3T3-L1 cells was also evident from the accumulation of intracellular lipid droplets for which the differentiation rate was $>90 \%$.

\section{Regulation of NMB expression in differentiated mur- ine adipocyte 3T3-L1 cells}

Differentiated murine adipocytes at day 11 were incubated for $24 \mathrm{~h}$ with leptin (1000, 100 and $10 \mathrm{nM}$ ), (IL6; $100 \mathrm{ng} / \mathrm{ml})$, (LPS; $75 \mathrm{ng} / \mathrm{ml}),\left(\mathrm{T}_{3} ; 1000 \mathrm{nM}, 100 \mathrm{nM}\right)$, $\left(\mathrm{T}_{4} ; 1000\right.$ and $\left.100 \mathrm{nM}\right)$ and $(\mathrm{Dex} ; 20 \mathrm{nM})$ and compared with control untreated cells (Fig. 5).

Addition of leptin resulted in a dose-dependent decrease in NMB mRNA expression $(P \leq 0 \cdot 05)$ measured using the Taqman assay (Fig. 5). This is in keeping with the in vivo studies showing a decrease in NMB mRNA in adipose tissue in response to i.p. administration of leptin to both lean and obese C57BL/6 mice (Fig. 2).

NMB expression was also decreased with $\mathrm{T}_{3}$ and $\mathrm{T}_{4}$ at the higher concentration $(1000 \mathrm{nM} ; P \leq 0 \cdot 05)$, LPS $(P \leq 0 \cdot 001)$ and IL6 $(P \leq 0 \cdot 01)$, while Dex increased NMB expression $(P \leq 0 \cdot 01$; Fig. 5$)$.

\section{Expression of NMB mRNA in murine adipose tissue decreased with increasing cold exposure in the C57BL/6 mouse}

To determine whether adipose tissue NMB mRNA is altered by cold exposure, we exposed C57BL/ 6 mice to periods of cold exposure spanning three orders of magnitude in duration from 6 to $6000 \mathrm{~min}$ and measured NMB mRNA by the Taqman assay in epididymal (Fig. 6a) and subcutaneous adipose tissue (Fig. 6b). Relative to the 6 min exposure, NMB mRNA expression was decreased 


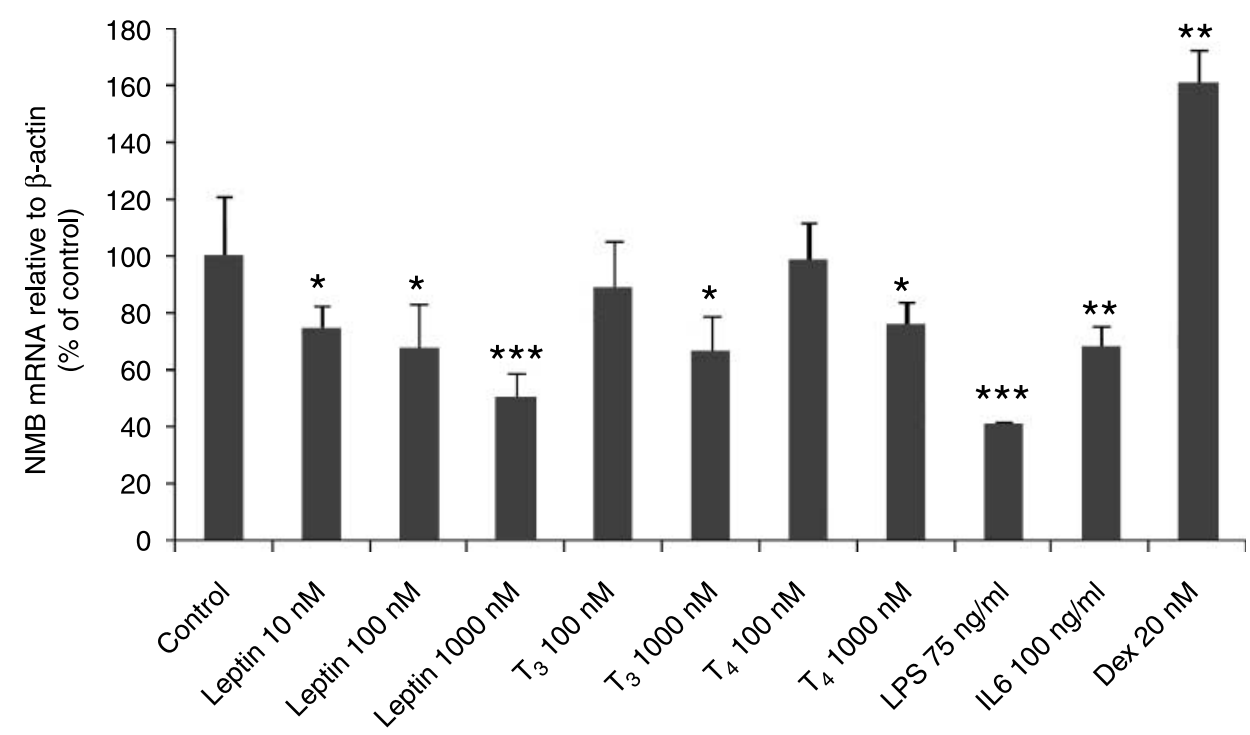

Figure 5 The addition of leptin (1000, 100 and $10 \mathrm{nM}$ ), $\mathrm{T}_{3}$ (triiodothyronine; $1000 \mathrm{nM}$ ), $\mathrm{T}_{4}$ (thyroxine; $1000 \mathrm{nM}$ ), LPS (lipopolysaccharide; $75 \mathrm{ng} / \mathrm{ml}$ ) and IL6 (interleukin 6; $100 \mathrm{ng} / \mathrm{ml}$ ) to primary cultures of differentiated adipocytes for $24 \mathrm{~h}$ significantly $(P \leq 0.05)$ inhibits NMB mRNA expression when compared with untreated control cells, while Dex (dexamethasone; $20 \mathrm{nM}$ ) stimulates NMB mRNA expression. No significant effect of $T_{3}(100 \mathrm{nM})$ and $\mathrm{T}_{4}(100 \mathrm{nM})$ was observed at the lower concentrations on NMB expression. NMB mRNA was determined by qRT-PCR using the Taqman assay and primers specific for murine NMB. Results are expressed as a percentage of the control untreated differentiated cells. $n=3$ for each point \pm S.E.M. related to the expression of the housekeeping gene $\beta$ actin. ${ }^{\star} P \leq 0.05,{ }^{\star \star} P \leq 0.01,{ }^{\star \star \star} P \leq 0.001$. This was replicated in independent amplifications.

with increasing cold exposure. This was significant at $600 \min (P \leq 0 \cdot 05)$. This suggests that peripheral NMB may have a role in thermoregulation or alternatively it may simply be part of the mechanism regulating food intake. In keeping with the role in thermoregulation, previous studies have shown that $\mathrm{BN}$ and the $\mathrm{BN}$-like peptides can affect metabolism (Wunder et al. 1980, Babcock et al. 1992, Itoh et al. 1995, Tsushima et al. 2003).

\section{Effect of NMB administered acutely to lean C57BL/6 mice on $\mathrm{O}_{2}$ consumption and $\mathrm{CO}_{2}$ production}

Mice were randomly allocated to the treatment groups. There were no significant differences in body mass or preinjection RMR between the treatment groups. A typical time course of $\mathrm{O}_{2}$ consumption for a single individual mouse injected with saline is shown in Fig. 7. This plot illustrates several features that were apparent in the traces of all animals. During the initial phase, after being introduced to the chamber, all the mice exhibited exploratory behaviour and their levels of $\mathrm{O}_{2}$ consumption remained elevated for around 50-60 min (Fig. 7B). They then settled and during the final $30 \mathrm{~min}$ (approximately) were generally observed to be asleep (Fig. 7C). Positive excursions of $\mathrm{O}_{2}$ consumption for brief periods coinciding with periods of activity were evident on the recordings (Fig. 7D). Following injection, the mice exhibited a second increase in $\mathrm{O}_{2}$ consumption coinciding with elevated activity on return to the chambers. Following this period, which lasted 20-30 min, the mice again settled down and positive excursions of the traces due to activity were again evident (Fig. $7 \mathrm{H})$. The pattern of change in the baseline resting $\mathrm{O}_{2}$ consumption underlying these changes due to activity were very similar between the control and NMB treatment. The mean $\mathrm{O}_{2}$ consumption averaged across all individuals in each treatment group is illustrated in Fig. 8a (saline) and Fig. 8b (NMB). In these plots, periods when all mice were active or had elevated resting metabolism show as positive excursions, while individual bouts of activity that were not coincident across individuals are damped by the average. In the pre-injection phase, both plots appear identical as would be expected since the groups were matched for body mass and at this point their treatments did not differ. In the saline (Fig. 8a) and NMB injected mice (Fig. 8b), the metabolic rate increased following return to the chamber after injection but then settled to a level where the minimal $\mathrm{O}_{2}$ consumption had declined slightly relative to that measured pre-injection.

Using the criterion of minimal resting $\mathrm{O}_{2}$ consumption measured over a continuous period of $150 \mathrm{~s}$ over the entire post-injection period, there was no significant effect of NMB when compared with saline, on resting $\mathrm{O}_{2}$ consumption.

Respiratory exchange ratio $(\mathrm{RQ})$ in the post-injection phase was not significantly $(P>0 \cdot 05)$ affected by 

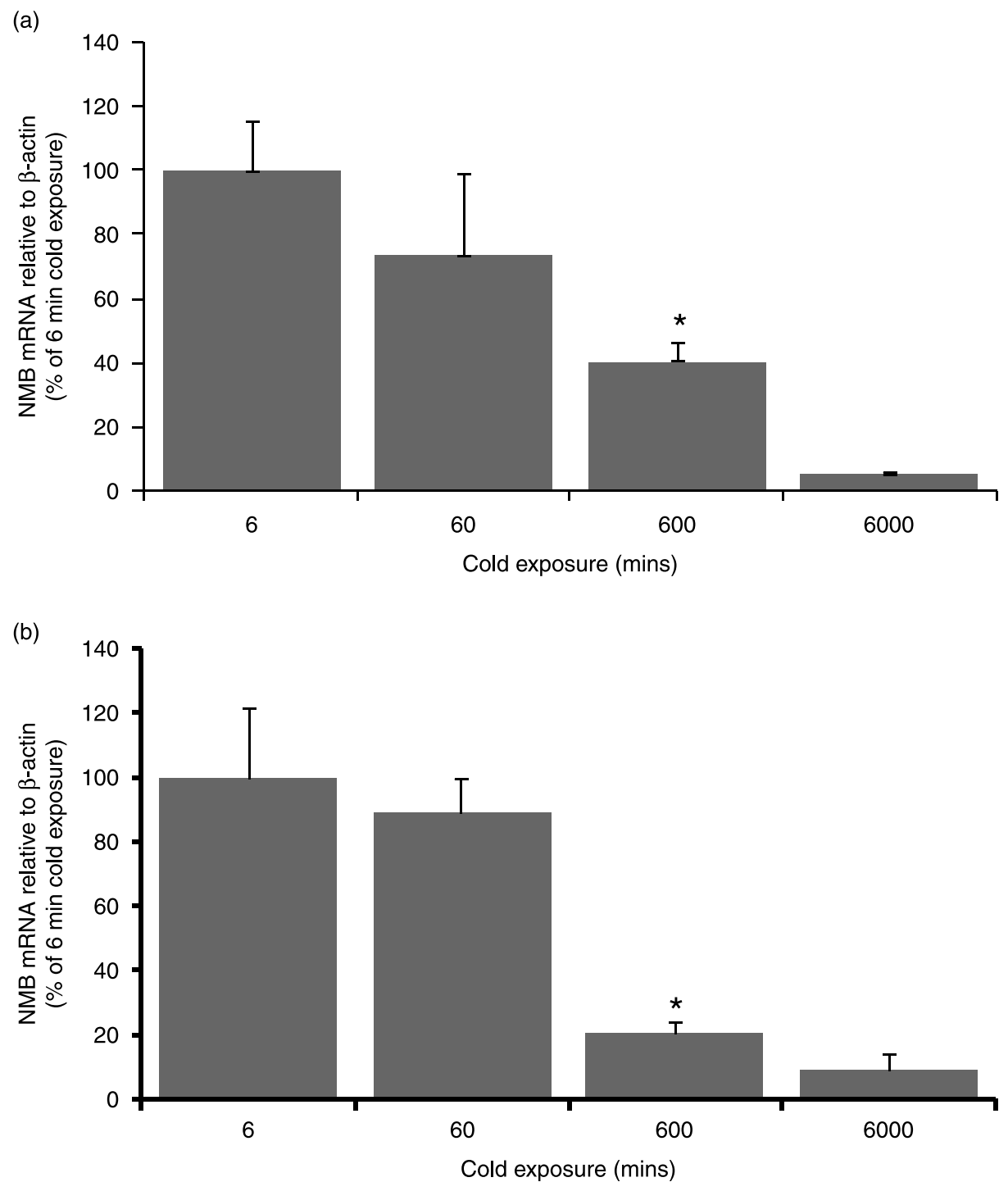

Figure 6 Expression of NMB mRNA in (a) murine epididymal and (b) subcutaneous adipose tissue is decreased upon cold exposure of the C57BL/6 mouse. The decrease in NMB increases with the increased exposure to cold at 6, 60, $600(P \leq 0.05)$ and 6000 min compared with the 6-min cold exposure. NMB mRNA was determined by qRT-PCR using the Taqman assay and primers specific for murine NMB. Results are expressed as a percentage of the NMB expression in the 6-min cold exposed fat depot (the highest expression), $n=5$ for each point \pm s.E.M. related to the expression of the housekeeping gene $\beta$-actin. This was replicated in independent amplifications.

treatment (data not shown). Levels of energy expended on spontaneous physical activity were also not significantly different either prior to injection $(P>0 \cdot 05)$ or during the post-injection phase $(P>0 \cdot 05)$.

In summary, the effect of $\mathrm{NMB}$ on $\mathrm{O}_{2}$ consumption was not significantly different from that of the saline control. This suggests that the NMB changes as a result of cold exposure were precipitated by changes in the cold and not part of the system up-regulating coldinduced thermogenesis.

\section{Discussion}

We have shown that NMB mRNA is expressed at high levels in adipose tissue when compared with a range of other tissues including the pituitary, a tissue where expression has previously been reported in the C57BL/6 mouse. Given that BN-like peptides including NMB and GRP administered both centrally and peripherally have previously been shown to inhibit food intake in a variety of species including humans (Merali et al. 1999, 


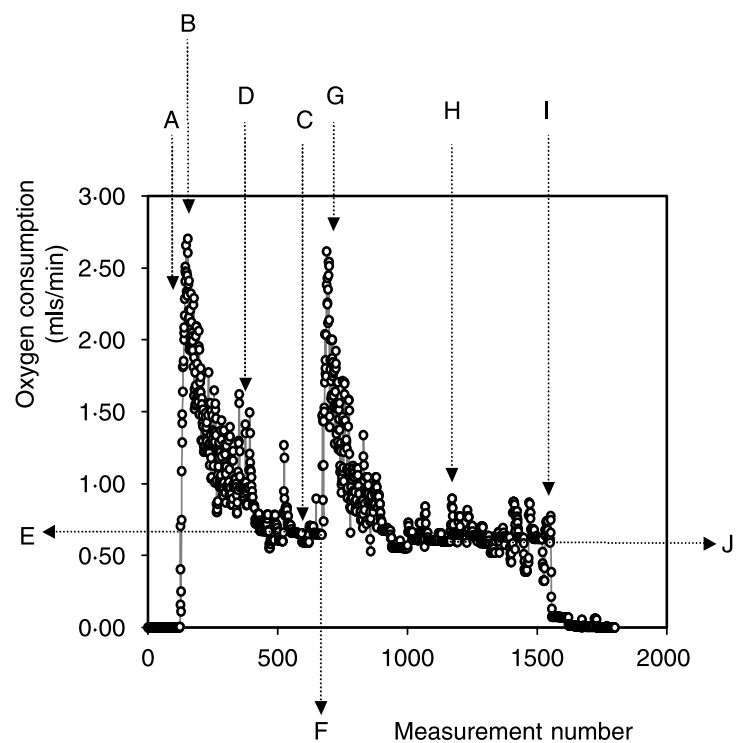

Figure 7 Typical time course of oxygen consumption observed in a C57BL/6 mouse during an experimental run to illustrate typical features of the change in metabolism over time. The animal is placed in the chamber at point $A$. The oxygen consumption increases at point $B$ reflecting activity of the animal in the chamber. The animal eventually falls asleep (point $\mathrm{C}$ ) although during the decline in metabolism there are still occasional excursions reflecting renewed activity (e.g. point D). The preinjection RMR is indicated by the level $E$. At $F$, the animal is removed from the chamber, rapidly injected i.p. with the treatment compound (in this case saline) and returned immediately into the chamber. As this is performed within a period of about $10 \mathrm{~s}$, during which the chamber is not ventilated, the analyser does not register a decline in the oxygen consumption. There is a second bout of activity $(G)$ following return to the chamber but the animal settled down more quickly in this case. Occasional elevations in metabolism due to activity are still observed in the post-injection phase $(\mathrm{H})$ and the animal is finally removed at point I. The postinjection level of resting metabolism is indicated by the level $\mathrm{J}$. Each measurement is $15 \mathrm{~s}$ apart.

Ladenheim \& Knipp 2007), we hypothesised that NMB expressed in adipose tissue may play a role in energy balance regulation. This may relate to its function in food intake regulation or to changes in energy expenditure. In support of this, we have shown that NMB expression is decreased in the adipose tissue of both obese $o b / o b$ and obese $d b / d b$ mice when compared with lean mice on the same C57BL/6 background. The administration of leptin peripherally to both lean and obese (leptin-deficient) $o b / o b$ mice caused a decrease in NMB expression in adipose tissue. This outcome is supported by our in vitro findings, which show a dosedependent inhibition of NMB mRNA by leptin in differentiated 3T3-L1 adipocytes. However, given that NMB is decreased in (leptin-deficient) obese $o b / o b$ mice when compared with lean control mice, it suggests that leptin is not the only signal regulating NMB. The possible regulation of NMB by the pituitary-thyroid axis and the pro-inflammatory response associated with obesity is discussed below. We further demonstrate that NMB expression in rodent adipose tissue is decreased in the subcutaneous fat depot of cold exposed animals. However, when we investigated the effects of NMB on RMR by i.p. injection ( $32 \mathrm{nmol} / \mathrm{kg}$ body weight) there was no effect on oxygen consumption, $\mathrm{RQ}$ or physical activity when compared with saline-treated controls.

BN-like peptides have a role in meal termination and are expressed in the gut as well as the brain. Accordingly, it has been proposed that NMB along with GRP may represent one of the physiological mediators of the gut-brain axis (Banks 1980, Gibbs 1985, Panula 1986, Merali et al. 1999). It has been proposed that $\mathrm{BN}-$ like peptides, including $\mathrm{NMB}$, are released in the GI tract in response to food, and bridge the gut-brain axis to inhibit further food intake (Merali et al. 1999). In keeping with this, it has been shown that $\mathrm{BN}$-like peptides are released into the intestinal mucosa in response to nutrients (Schusdziarra et al. 1986). Ladenheim et al. (1996a,b, 1997) have shown that peripherally injected $\mathrm{BN}$ decreased food intake via $\mathrm{BN}$ receptors of both GRP and NMB subtypes in the caudal hindbrain. There have been a number of reports where BN/BN-like peptides administered into the hypothalamus induce hypophagia (Stuckey \& Gibbs 1982, Kyrkouli et al. 1987, Hillebrand et al. 2002). The release of BN-like peptides in the paraventricular nucleus (PVN) has been shown to depend on the ingestion of food (Plamondon \& Merali 1994). Taken together, this clearly demonstrates the importance of the $\mathrm{BN}$ receptor family in the CNS in the regulation of feeding behaviour (Merali et al. 1999). NMB expressed in adipose tissue may therefore regulate food intake over the longer term. In keeping with BN-like peptides suppressing food intake, levels of NMB in the adipose tissue of obese (leptin-deficient) $o b / o b$ mice are low compared with their lean littermates.

The process through which the BN-like peptides of peripheral origin activate the relevant brain circuits remains to be identified. Although these peptides of peripheral origin may not readily cross the blood brain barrier, they may have some access at sites where the barrier is less restrictive (such as the area postrema; Banks \& Kastin 1989, 1990). It has also been suggested that peripheral BN from the gut suppresses food intake via spinal afferent fibres along with vagal afferent mechanisms that ultimately elicit the release of BN-like peptides within the CNS (Merali et al. 1999, Michaud et al. 1999).

We have shown that the administration of leptin peripherally to both lean and obese (leptin-deficient) $o b / o b$ mice causes a decrease in NMB expression in adipose tissue. This is supported by our in vitro findings, which show a dose-dependent inhibition of NMB mRNA by leptin in differentiated 3T3-L1 adipocytes. This finds resonance with previous studies, where peripheral 
(a)

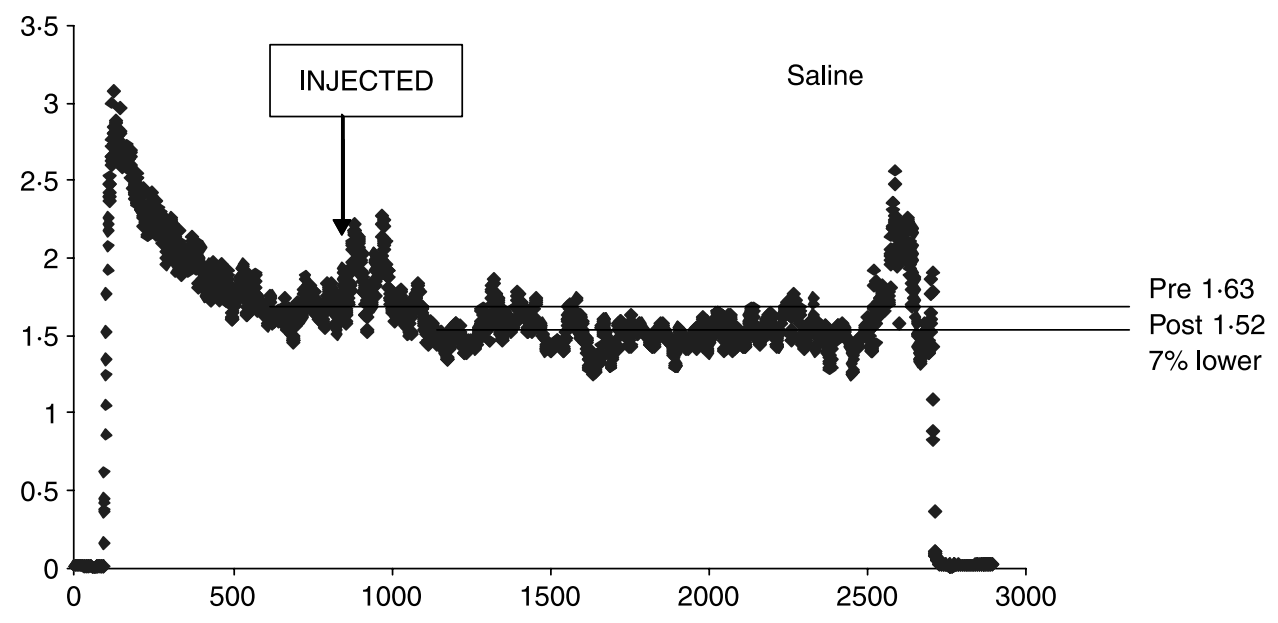

(b)

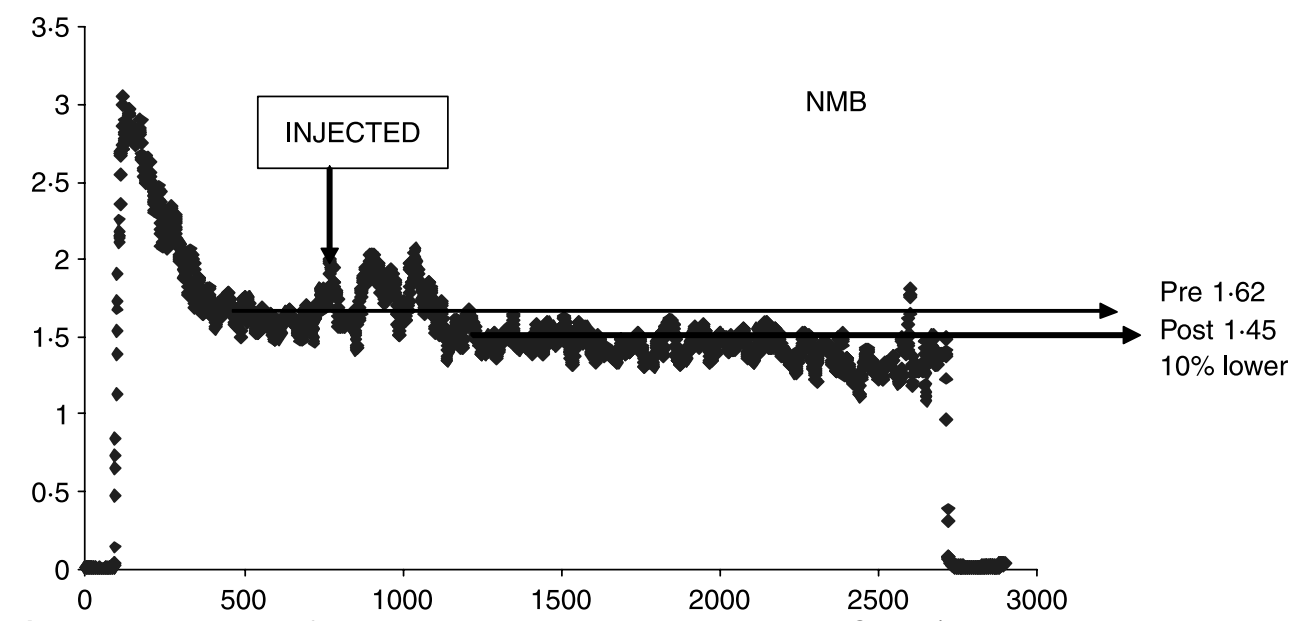

Figure 8 Time courses of oxygen consumption averaged across eight C57BL/6 mice in each group injected with either (a) saline $(200 \mu \mathrm{l})$ or (b) NMB (32 nmol/kg body weight) in saline. In saline and NMB injected mice, there was no difference between the pre-injection and post-injection levels of resting metabolism.

administration of leptin to rats $(8 \mu \mathrm{g} / 100 \mathrm{~g}$ body weight $)$ caused a $30 \%$ reduction in $\mathrm{NMB}$ concentration in the pituitary when compared with saline-treated controls (Ortiga-Carvalho et al. 2002). In the pituitary, the inhibition of NMB by leptin occurs either by a direct action of leptin on the pituitary or indirectly via a stimulation of thyrotropin-releasing hormone (TRH). TRH has also been shown to reduce NMB concentration in the pituitary by up to $45 \%$ when administered peripherally to rats compared with saline-treated controls (Ortiga-Carvalho et al. 2002). Serum $\mathrm{T}_{3}$ is also reduced in $\mathrm{NMB}$ receptor knockout mice, which taken together suggests that NMB may be important in the pituitarythyroid axis (Oliveira et al. 2006). To investigate this further in adipose tissue, we determined whether $\mathrm{T}_{3}$ or $\mathrm{T}_{4}$ had a direct effect on NMB expression in differentiated
3T3-L1 adipocytes. Although only significant at the higher concentrations $(1000 \mathrm{nM})$, we were able to show that both $\mathrm{T}_{3}$ and $\mathrm{T}_{4}$ inhibit $\mathrm{NMB}$ expression. However, it should be noted that these levels are tenfold higher than the physiological levels of $\mathrm{T}_{3} / \mathrm{T}_{4}(\sim 10 \mathrm{nM})$.

I.c.v. injections of $\mathrm{BN}$ and the $\mathrm{BN}$-like peptides have been shown to produce significant dose-dependent hypothermia in rodents (Wunder et al. 1980, Babcock et al. 1992, Itoh et al. 1995, Tsushima et al. 2003). However, there is another study that suggests that peripheral administration of $\mathrm{BN}$ increased metabolism (Even et al. 1991). Because of this conflict and the effect we observed of both $\mathrm{T}_{3}$ and $\mathrm{T}_{4}$ on the expression of $\mathrm{NMB}$ in adipocytes, which have also been shown to affect metabolic rate, we determined whether peripheral i.p. administration of NMB had a significant effect 
on energy expenditure. Support for this hypothesis comes from our demonstration that NMB is decreased in adipose tissue as a result of cold exposure. However, when we studied the acute effect of NMB using openflow indirect calorimetry apparatus, we observed no effect on RMR at the concentration used $(32 \mathrm{nmol} / \mathrm{kg}$ body), which we selected because it was a similar dose to that used in previous studies. This suggests that the NMB changes as a result of cold exposure were not part of the system up-regulating cold-induced thermogenesis, but the changes may be part of the mechanism regulating food intake. The decrease we observed in NMB during the cold exposure may be a result of changes in $T_{3}$ and $T_{4}$ that are activated as a result of cold exposure. A similar decrease in NMB in the pituitary upon cold exposure has been reported previously (Ortiga-Carvalho et al. 2003). The changes in NMB expression in adipose tissue as a result of cold exposure may be as a result of changes in energy fluxes stimulating an increase in food intake.

Receptors to NMB have been reported in adipose tissue, which suggests that NMB may have important autocrine effects. In keeping with this, NMB has been shown to induce mitogenesis in adipocyte 3T3 cells (Zachary \& Rozengurt 1985). Indeed, using 3T3-L1 cells, the present study indicates that the expression of NMB mRNA is greater in preadipocytes than in differentiated mature adipocytes supporting a role for NMB in preadipocyte mitogenesis. It may be that expression of NMB is more important in preadipocytes; however, significant levels of NMB are detected in the mature adipocytes and adipose tissue itself. In addition, NMB is detected at significant levels in the stromal vascular fraction, which could reflect expression in any component of that fraction, including fibroblasts, vascular endothelial cells and immune cells (including mast cells and macrophages) in addition to immature adipocytes. This suggests that there might be an interaction between the cells of the stromal vascular fraction and the mature adipocytes, which expresses receptors to NMB. It is interesting to note that we also show that NMB expression is decreased by IL6, which is part of the obesity associated inflammatory response and by LPS, which stimulates an inflammatory response (Trayhurn \& Wood 2004). This may be one pathway by which NMB expression in the adipose tissue is reduced in the obese $o b / o b$ mouse when compared with the lean control mouse. IL6 and other inflammatory cytokines are increased with increasing adiposity in the obese $o b / o b$ mouse. As we discussed above, it is unlikely that leptin is responsible for the decrease in NMB in the leptin-deficient $o b / o b$ mouse, as we have shown that leptin causes a reduction in NMB expression.

In humans, Bouchard et al. (2004) have identified a missense mutation in the NMB gene, which was associated with twice as much body fat gain over a 6 -year follow-up period compared with the wild type population. In keeping with a role for NMB in energy balance in humans, we have also shown that NMB mRNA is present in human adipose tissue at levels comparable with those in rodent adipose tissue.

In conclusion, this is the first report of NMB expression in adipose tissue. We provide evidence to support a possible role of $\mathrm{NMB}$ in the regulation of energy balance. Given the anorexic effects of BN-like peptides centrally, NMB expressed by adipose tissue may form part of a new adipose tissue hypothalamic axis regulating food intake.

\section{Acknowledgements}

This work was supported by a grant from the Scottish Executive Environment and Rural Affairs Department (SEERAD). The authors declare that there is no conflict of interest that would prejudice the impartiality of this scientific work.

\section{References}

Anastasi A, Erspamer V \& Bucci M 1971 Isolation and structure of bombesin and alytesin, 2 analogous active peptides from the skin of the European amphibians Bombina and Alytes. Experientia 27 166-167.

Arch JR, Hislop D, Wang SJ \& Speakman JR 2006 Some mathematical and technical issues in the measurement and interpretation of open-circuit indirect calorimetry in small animals. International Journal of Obesity 30 1322-1331.

Babcock AM, Baker DA \& Moody TW 1992 Bombesin-induced hypothermia: a dose-response and receptor antagonist study. Pharmacology, Biochemistry and Behavior 43 957-960.

Banks WA 1980 Evidence for a cholecystokinin gut-brain axis with modulation by bombesin. Peptides 1 347-351.

Banks WA \& Kastin AJ 1989 Quantifying carrier-mediated transport of peptides from the brain to the blood. Methods in Enzymology 168 652-660.

Banks WA \& Kastin AJ 1990 Exchange of peptides between the circulation and the nervous system: role of the blood-brain barrier. Advances in Experimental Medicine and Biology 274 59-69.

Bouchard L, Drapeau V, Provencher V, Lemieux S, Chagnon Y, Rice T, Rao DC, Vohl MC, Tremblay A, Bouchard C et al. 2004 Neuromedin $\beta$ : a strong candidate gene linking eating behaviors and susceptibility to obesity. American Journal of Clinical Nutrition 80 1478-1486.

Erspamer V, Erpamer GF \& Inselvini M 1970 Some pharmacological actions of alytesin and bombesin. Journal of Pharmacy and Pharmacology 22 875-876.

Even PC, de Saint Hilaire Z \& Nicolaidis S 1991 Peripheral administration of bombesin increases metabolism in the rat. Physiology and Behavior 49 439-442.

Gibbs J 1985 Effect of bombesin on feeding behavior. Life Sciences 37 $147-153$.

Hillebrand JJ, de Wied D \& Adan RA 2002 Neuropeptides, food intake and body weight regulation: a hypothalamic focus. Peptides 23 2283-2306.

Hoggard N, Rayner DV, Johnston SL \& Speakman JR 2004 Peripherally administered [Nle4,D-Phe7]- $\alpha$-melanocyte stimulating hormone increases resting metabolic rate, while peripheral agouti-related protein has no effect, in wild type C57BL/6 and $o b / o b$ mice. Journal of Molecular Endocrinology 33 693-703. 
Houben H, Vandenbroucke AT, Verheyden AM \& Denef C 1993 Expression of the genes encoding bombesin-related peptides and their receptors in anterior pituitary tissue. Molecular and Cellular Endocrinology 97 159-164.

Itoh S, Takashima A, Itoh T \& Morimoto T 1995 Effects of neuromedins and related peptides on the body temperature of rats. Japanese Journal of Physiology 45 37-45.

Kyrkouli SE, Stanley BG \& Leibowitz SF 1987 Bombesin-induced anorexia: sites of action in the rat brain. Peptides 8 237-241.

Ladenheim EE \& Knipp S 2007 Capsaicin treatment differentially affects feeding suppression by bombesin-like peptides. Physiology and Behavior 91 36-41.

Ladenheim EE, Taylor JE, Coy DH, Moore KA \& Moran TH $1996 a$ Hindbrain GRP receptor blockade antagonizes feeding suppression by peripherally administered GRP. American Journal of Physiology 271 R180-R184.

Ladenheim EE, Wirth KE \& Moran TH $1996 b$ Receptor subtype mediation of feeding suppression by bombesin-like peptides. Pharmacology, Biochemistry and Behavior 54 705-711.

Ladenheim EE, Taylor JE, Coy DH, Carrigan TS, Wohn A \& Moran TH 1997 Caudal hindbrain neuromedin B-preferring receptors participate in the control of food intake. American Journal of Physiology 272 R433-R437.

Ladenheim EE, Hampton LL, Whitney AC, White WO, Battey JF \& Moran TH 2002 Disruptions in feeding and body weight control in gastrin-releasing peptide receptor deficient mice. Journal of Endocrinology 174 273-281.

McDonald TJ, Jornvall H, Nilsson G, Vagne M, Ghatei M, Bloom SR \& Mutt V 1979 Characterization of a gastrin releasing peptide from porcine non-antral gastric tissue. Biochemical and Biophysical Research Communications 90 227-233.

Merali Z, McIntosh J \& Anisman H 1999 Role of bombesin-related peptides in the control of food intake. Neuropeptides 33 376-386.

Michaud D, Anisman H \& Merali Z 1999 Capsaicin-sensitive fibers are required for the anorexic action of systemic but not central bombesin. American Journal of Physiology 276 R1617-R1622.

Minamino N, Kangawa K \& Matsuo H 1988 Neuromedin B and neuromedin Ca. Two mammalian bombesin-like peptides identified in porcine spinal cord and brain. Annals of the New York Academy of Sciences $\mathbf{5 4 7}$ 373-390.

Moody TW \& Merali Z 2004 Bombesin-like peptides and associated receptors within the brain: distribution and behavioral implications. Peptides 25 511-520.

Nagalla SR, Barry BJ, Creswick KC, Eden P, Taylor JT \& Spindel ER 1995 Cloning of a receptor for amphibian (Phe13) bombesin distinct from the receptor for gastrin-releasing peptide: identification of a fourth bombesin receptor subtype (BB4). PNAS 92 6205-6209.

Ohki-Hamazaki H, Watase K, Yamamoto K, Ogura H, Yamano M, Yamada K, Maeno H, Imaki J, Kikuyama S, Wada E et al. 1997 Mice lacking bombesin receptor subtype-3 develop metabolic defects and obesity. Nature 390 165-169.
Ohki-Hamazaki H, Iwabuchi M \& Maekawa F 2005 Development and function of bombesin-like peptides and their receptors. International Journal of Developmental Biology 49 293-300.

Oliveira KJ, Ortiga-Carvalho TM, Cabanelas A, Veiga MA, Aoki K, OhkiHamazaki H, Wada K, Wada E \& Pazos-Moura CC 2006 Disruption of neuromedin $\mathrm{B}$ receptor gene results in dysregulation of the pituitarythyroid axis. Journal of Molecular Endocrinology 36 73-80.

Ortiga-Carvalho TM, Oliveira KJ, Soares BA \& Pazos-Moura CC 2002 The role of leptin in the regulation of TSH secretion in the fed state: in vivo and in vitro studies. Journal of Endocrinology 174 121-125.

Ortiga-Carvalho TM, Oliveira K, de J, Morales MM, Martins VP \& Pazos-Moura CC 2003 Thyrotropin secretagogues reduce rat pituitary neuromedin B, a local thyrotropin release inhibitor. Experimental Biology and Medicine 228 1083-1088.

Panula P 1986 Histochemistry and function of bombesin-like peptides. Medical Biology 64 177-192.

Plamondon H \& Merali Z 1994 Push-pull perfusion reveals mealdependent changes in the release of bombesin-like peptides in the rat paraventricular nucleus. Brain Research 668 54-61.

Rentsch J \& Chiesi M 1996 Regulation of $O b$ gene messenger-RNA levels in cultured adipocytes. FEBS Letters 379 55-59.

Schusdziarra V, Schmid R \& Classen M 1986 Modulatory glucose effect on bombesin-like immunoreactivity and gastrin secretion from isolated perfused rat stomach. Diabetes 35 791-796.

Stuckey JA \& Gibbs J 1982 Lateral hypothalamic injection of bombesin decreases food intake in rats. Brain Research Bulletin 8 617-621.

Trayhurn P \& Wood IS 2004 Adipokines: inflammation and the pleiotropic role of white adipose tissue. British Journal of Nutrition 92 347-355.

Tsushima H, Mori M, Fujiwara N \& Moriyama A 2003 Pharmacological characteristics of bombesin receptor mediating hypothermia in the central nervous system of rats. Brain Research 969 88-94.

Wunder BA, Hawkins MF, Avery DD \& Swan H 1980 The effects of bombesin injected into the anterior and posterior hypothalamus on body temperature and oxygen consumption. Neuropharmacology 19 1095-1097.

Yamano M, Ogura H, Okuyama S \& Ohki-Hamazaki H 2002 Modulation of 5-HT system in mice with a targeted disruption of neuromedin B receptor. Journal of Neuroscience Research 68 $59-64$.

Yang YS, Song HD, Li RY, Zhou LB, Zhu ZD, Hu RM, Han ZG \& Chen JL 2003 The gene expression profiling of human visceral adipose tissue and its secretory functions. Biochemical and Biophysical Research Communications 300 839-846.

Zachary I \& Rozengurt E 1985 High-affinity receptors for peptides of the bombesin family in Swiss 3T3 cells. PNAS 82 7616-7620.

Received in final form 12 July 2007

Accepted 20 July 2007

Made available online as an Accepted Preprint

24 July 2007 